\title{
Ivan Šiber
}

\section{RAZVOJ POLITIČKE PSIHOLOGIJE U HRVATSKOJ}

DOI $10.17234 / 9789531757782.7$

Uvod

Što je uopće politička psihologija?

Odrediti predmet neke znanosti, znanstvene discipline ili primijenjenog područja je kompleksan zadatak. Teorijske definicije, posebice u području društvenih i humanističkih znanosti, izrazito su rijetke. Obično se pribjegava deskripciji područja, navođenju problema i sl. Politička psihologija je svakako primijenjeno područje psihologije, prije svega socijalne psihologije, ali ujedno i interdisciplinarno područje koje zahtijeva sociološke, politološke, historiografske analize te znanja iz drugih disciplina kao što su antropologija i ekonomija. Moglo bi se reći, slično određenju koje daje Zvonarević (1976) za socijalnu psihologiju, da politička psihologija istražuje psihološke aspekte političkih pojava i političke aspekte psiholoških pojava. Politička psihologija određena je političkim fenomenima: što politika postaje rasprostranjenija u nekom društvu i što je veća angažiranost pojedinaca u političkim procesima, to je veće i područje političke psihologije. Drugim riječima, razvoj društva i uloga pojedinca i drugih društvenih agregata kao nositelja političke akcije određuje i domenu političke psihologije.

U pregledu područja političke psihologije Hermann (1986) ukazuje na pet temeljnih polazišta:

- Usredotočenost na interakciju političkih i psiholoških pojava. Kako psihološki čimbenici određuju političko ponašanje i kako političke akcije utječu na psihološke varijable? Percepcije, vjerovanja, motivi, mišljenja, vrijednosti, interesi, osobni stil i obrambeni mehanizmi pojedinca utječu na to kako će se oni ponašati i politički djelovati. Jednako tako, politička kultura, politički sustav, mehanizmi političke socijalizacije, politički pokreti i stranke, kao i međunarodni poredak, utječu na to kako će se ljudi formirati kao politička bića.

\footnotetext{
Dijelovi ovog teksta prethodno su objavljeni u sljedećim publikacijama: Psihologijski aspekti međunacionalnih odnosa (1988); Autoritarna struktura ličnosti - kritički prikaz jugoslavenskih istraživanja (1989); Osnove političke psihologije (1998); Političko ponašanje - istraživanja hrvatskog društva (2007).
} 
- Politička psihologija je relevantna za mnoge socijetalne probleme. Interes za ovo područje rezultat je činjenice da su mnogi društveni problemi izrazito politizirani, od zaštite okoliša do međuetničkih odnosa.

- Konkretna socijalna (politička) situacija dovodi do razlika medu ljudima. Politička psihologija uvijek proučava pojedinca i grupe u određenom vremenu i prostoru, odnosno u određenom političkom sustavu i kulturi. Tu se postavlja problem što je to ljudima zajedničko u političkom ponašanju, neovisno o konkretnim političkim i kulturnim okolnostima, a što je različito, odnosno ovisno o tim okolnostima.

- Upolitičkoj psihologiji naglasak je na procesu političkog ponašanja i na rezultatu tog ponašanja. Kako se birači opredjeljuju? Kako se mogu razriješiti politički sukobi? Kako se odvija proces informiranja? Kako vođe mobiliziraju sljedbenike? Kako se politički socijaliziraju mladi?

- Politička psihologija se temelji na različitim metodama analiza i prikupljanja podataka. Ova potreba za različitim metodološkim pristupima proizlazi iz činjenice određene multidisciplinarnosti predmeta političke psihologije. Naime, predmet političke psihologije je određen samim političkim fenomenom koji je izrazito promjenljiv, koji utječe na ostale sfere socijetalnih procesa i dobiva veoma različite oblike u vremenu i prostoru.

\section{Razvoj političke psihologije u svijetu}

Svaka se znanost razvija u kontekstu ostalih znanosti i moraju postojati određene metodološke i spoznajne pretpostavke za njezin razvoj. Jednako tako potrebna je i povoljna društvena situacija, odnosno postojanje određene društvene potrebe koje traže znanstvene odgovore. Upravo razdoblje s početka 20. stoljeća jednostavno zahtjeva socijalnu i političku psihologiju. To je vrijeme naglog razvoja industrijskog društva koje stavlja ljude u specifične situacije međusobne interakcije značajne za samu proizvodnju, kao i razdoblje jačanja građanskog društva, parlamentarne demokracije, općih izbora, koje također zahtijeva razumijevanje osobina čovjeka kao socijalne jedinke, kao subjekta i objekta tih zbivanja.

Već 1909. Wallas ukazuje na važnost psihologijskih aspekata naglašavajući da skoro svi istraživači u području politike analiziraju institucije, a izbjegavaju analizu čovjeka, $\mathrm{i}$ istovremeno naglašavaju ograničenost njegovih racionalnih kapaciteta.

Američki publicist i znanstvenik Lippman (1922) također uviđa zapostavljenost analize čovjeka u dotadašnjim politološkim pristupima i kaže: „Govoriti o politici a ne obazirati se na ljudska bića, zapravo je najveća pogreška u našem političkom mišljenju."

Slično mišljenje imaju i politolozi, tako da, na primjer, američki politolog Eulau (1963) naglašava: „Čovjek je korijen. Mislim da je nemoguće reći išta smisleno o 
upravi, a da se ne govori o političkom ponašanju čovjeka, o njegovim ciljevima, nagonima, osjećajima, vjerovanjima, vrijednostima."

Problematika političke psihologije istraživala se usporedo s razvojem socijalne psihologije. Samo kao primjer možemo navesti istraživanja stavova koja su u samom početku bila istraživanja političkih stavova (Thurstone, 1928; Ferguson, 1939; Eysenck, 1944.), pokušaji operacionalizacije ideologijske orijentacije (liberalno-konzervativno; lijevo-desno), odnosno Bogardusova (1925) istraživanja fenomena socijalne distance, prije svega između pojedinih etničkih skupina.

\section{Razvoj političke psihologije u Hrvatskoj}

Formalno, ali i sadržajno, politička psihologija pojavljuje se osnivanjem Fakulteta političkih znanosti na Sveučilištu u Zagrebu 1962. godine kao jedan od obaveznih kolegija u nastavnom planu (puni naziv kolegija bio je Osnove socijalne i političke psihologije). Pri tome je interesantno naglasiti da se prvi relevantan udžbenik političke psihologije u svijetu pojavio tek deset godina kasnije (Knutson, 1973), a svjetsko udruženje za političku psihologiju utemeljeno je tek 1978. godine. Navodimo te činjenice kako bismo pokazali da se već prilikom formalnog utemeljenja političkih znanosti kod nas vodilo računa o svjetskim trendovima razvoja znanosti i da su osnivači bili svjesni dalekosežnosti tog projekta. ${ }^{2}$

$S$ obzirom na prirodu tadašnjeg političkog poretka kod nas, ali i dramatičnih promjena 1990. godine uvođenjem višestranačke parlamentarne demokracije, nužno je prikaz razvoja političke psihologije podijeliti u dva razdoblja: razdoblje pokušaja izgradnje socijalističkog samoupravnog društva (u osnovi totalitarnog poretka), i razdoblje uspostave demokratskog poretka. Kako smo to već naglasili, stvarni društveni odnosi i problemi određuju predmet istraživanja tako da niz problema suvremene političke psihologije prije 1990. godine jednostavno nije bio dostupan istraživanju, $s$ jedne strane zbog postojanja niza društvenih zabrana, a s druge, zbog činjenice da priroda političkog sustava nije omogućavala izbor između različitih političkih opcija, što i je u osnovi političke psihologije i njene društvene primjene.

Postoje dva problema s kojima se suočavamo u prikazu razvoja političke psihologije. Prvi je pitanje do koje mjere, zbog interdisciplinarnosti problematike, neko istraživanje pripada u političku psihologiju, odnosno u sociologiju ili politologiju. Mogli bismo, naravno, poći od selektivnog pristupa pa se zadržati isključivo na radovima psihologa. ${ }^{3}$ Budući da ne postoji jednoznačan kriterij, u ovom ćemo se

2 Veliku i odlučujuću ulogu u tome imao je Mladen Zvonarević, u to vrijeme profesor u Odsjeku za psihologiju Filozofskog fakulteta Sveučilišta u Zagrebu.

3 Samo kao ilustracija ograničenosti takvog pristupa može se navesti primjer D. Riesmana koji je zatražio prijem u Američko sociološko udruženje nakon što je objavio knjigu Usamljena gomila (1950). Nije primljen s obrazloženjem da nije diplomirani sociolog. Početkom 2000. o njemu se piše kao posljednjem živom velikanu američke sociologije 20. stoljeća! Slično bi bilo kada bi se iz prikaza razvoja industrijske psihologije izostavio F. Taylor s obrazloženjem da nije psiholog već inženjer. 
prikazu prikloniti osobnoj ocjeni o pojedinom radu imajući u vidu interesantnu distinkciju koju navodi Zvonarević (1976) o odnosu socijalne psihologije i sociologije. Prema njemu, „Kriterij za pripadnost neke metode psihologiji, odnosno socijalnoj psihologiji, jasan je i jednostavan, a nalazi se u općoj metodi psihologije, u introspekciji“" (str. 10).

Drugi je problem treba li se u ovom prikazu zadržati isključivo na autorima iz Hrvatske ili treba uzeti u obzir i radove autora iz ostalih dijelova tadašnje Jugoslavije. Budući da se ipak radilo o zajedničkoj državi, izrazito razvijenoj znanstvenoj suradnji, i, ne najmanje važno, zajedničkim problemima, smatramo da je ne samo korektno, već i znatno informativnije prikazati radove i autora izvan Hrvatske.

Isto tako nužno je upozoriti da u ovom pregledu nisu obuhvaćeni svi radovi iz ovog područja, već prije svega oni koji su otvorili nove probleme i pristupe.

\section{Radovi iz područja političke psihologije do 1990. - rani radovi}

Priroda političkog sustava nužno je stavljala određena ograničenja istraživanju problematike koja pripada u područje političke psihologije. Ta ograničenja bila su dvojaka: $s$ jedne strane, nepostojanje slobode političkog opredjeljenja, odnosno višestranačkog sustava, a s druge, represivni karakter društva koji, u najmanju ruku, nije podržavao, a ponekad i implicite i eksplicite onemogućavao istraživanje nekih problema. Ipak, kao što ćemo vidjeti, postoji niz istraživačkih radova koji su pružili relevantne uvide u mnoge iznimno važne probleme za razumijevanje „ljudskog“ faktora u okviru tadašnjega političkog sustava.

\section{Istraživanja psihologije izbornog ponašanja}

Prvi objavljeni radovi su iz područja izbornog ponašanja. Polemičko pitanje o istraživanju politike kada politike nema koje postavlja Prpić (2002) u svom eseju o Fakultetu političkih znanosti u Zagrebu i razvoju političkih znanosti u bivšoj Jugoslaviji, bez ostatka se može primijeniti i na problematiku istraživanja izbora. Za izborne sustave i izborno ponašanje uobičava se reći da su to „područja nad kojima politička znanost zasigurno posjeduje znanstveni legitimitet, ako ne i monopol“, odnosno „ako znanost u političkoj znanosti postoji, tada je to na predmetu izbora" (Grdešić i Šiber, 1991:, str. 5).

Je li moguće u okviru jednostranačkog monopola i ,samorazumljivog“ nositelja vlasti analizirati izborno ponašanje? Ako da, što se uopće može istraživati i kakva je svrha takvih istraživanja?

Prvo istraživanje ponašanja birača u Hrvatskoj, ali i u cijeloj tadašnjoj Jugoslaviji, provedeno je 1965. godine prilikom izbora za općinske skupštine u gradu Zagrebu (Zvonarević, Kljaić i Šiber, 1966). To su prvi izbori kada je uvedena mogućnost biranja između većeg broja kandidata. Elementarna pretpostavka biranja je znanje ponuđenih modaliteta, u ovom slučaju poznavanja imena kandidata. Upravo zato 
je u ovom istraživanju primijenjen postupak ispitivanja neposrednog pamćenja, odnosno neposredno po izlasku s birališta (tzv. izlazna anketa) biraču je pristupio anketar i zamolio ga ako se može sjetiti nekog imena s izborne liste. Prema tome, birač je tek koju minutu ranije držao u rukama izbornu listu te, čak i da nije od ranije znao kandidata, mogao se sjetiti nekog od imena koje je netom pročitao. Zbog toga je zadatak birača bio osobito lagan - s obzirom na mogućnost neposrednog dosjećanja - pa se njegov neuspjeh da reproducira barem jedno ime s izborne liste ne može interpretirati drugačije nego kao potpuno nepoznavanje kandidata između kojih je 'izabrao', odnosno kao neposredan pokazatelj nezainteresiranosti za sam rezultat izbora. Konačan nalaz istraživanja sam po sebi dovoljno govori o karakteru i motivacijskoj snazi izbora u to vrijeme $-52 \%$ ispitanika neposredno po izlasku s birališta nije znalo ni jedno jedino ime s liste kandidata!

U okviru izbora 1967. godine za tadašnju Saveznu skupštinu po prvi puta je primijenjena metoda panel ankete (Šiber, 1970), odnosno ispitivanje istih ispitanika u nekoliko navrata izborne kampanje. ${ }^{4}$ Nalazi istraživanja u zaključku rada komentirani su na sljedeći način: „U svakom slučaju ako bismo željeli zajednički interpretirati ove podatke onda moramo reći da stvarno učešće birača (operacionalizirano kroz znanje kao nužnu pretpostavku) nije u skladu s intencijama izbornog sustava. Ti se podaci mogu interpretirati kao rezultat neodgovarajuće pažnje izbornim procesima, neprimjerenim procesima informiranja, nedovoljnoj aktivnosti društveno političkih organizacija, nedovoljnoj svijesti biračkog tijela i slično, ali nama se čini da bi ovo sve bili površni argumenti. Čini nam se da je točnije reći da je stavljanje težišta na ličnost pojedinca kao određeni, uvjetno rečeno, kompromis između plebiscitarnih izbora i višestranačkog sustava neprimjereno i nedovoljno za realizaciju željenog društvenog odnosa. Ne samo što birači i nadalje pristupaju izborima po inerciji ranijeg vrednovanja već je pitanje do kakvih bi stvarnih društvenih procesa i promjena mogla dovesti činjenica da birači poznaju i biraju najbolje kandidate" (Šiber, 1970).

M. Benc (1969) je analizirao izbore na temelju rezultata izborne statistike (tzv. ekološki pristup, odnosno studij agregata) i pokazao znatne razlike u izlasku na izbore u različitim dijelovima Hrvatske. Ključni nalaz njegove analize je da birači u manjim seoskim sredinama znatno više izlaze na izbore nego u gradovima. Taj nalaz je svojevrsna konstanta i u izlasku na izbore nakon demokratskih promjena. Pokazuje se svojevrsna zakonitost da tzv. zatvorene socijalne sredine svojom unutarnjom socijalnom dinamikom potiču izlazak na izbore. Tu se, vjerojatno, radi o mehanizmima psihosocijalne interakcije kao što su socijalni pritisak ili imitacija, ali i konformizmu kod obavljanja građanske dužnosti.

Svakako da izborne kampanje u to vrijeme nisu imale obilježja suvremenih kampanja u višestranačkim demokracijama, ali je ipak postojala određena vremenska dimenzija predlaganja, rasprave i informiranja građana. 
Uvođenjem delegatskog sustava po prvi puta problematika znanstvenog istraživanja izbora prestaje biti isključivo predmet pojedinačnog interesa već postaje predmet dugoročnog istraživačkog projekta provedenog na Fakultetu političkih znanosti. Uvođenjem delegatskog sustava pokušavao se realizirati neposredan interes biračkog tijela u kontinuiranom procesu interakcija: biračko tijelo (delegatska osnova) - delegacije - delegat - delegatsko tijelo. Analize izbora 1978., 1982., i 1986. objavljene su u mnogim tekstovima od kojih navodimo dva najvažnija. Jedno je knjiga Delegatski sustav 1974-1984 (Šiber i Tomac, 1986), a drugo je monografija Delegatski izbori 1978-1986 (Kasapović, 1987) koja je bila neposredna kritika postojećeg izbornog modela i dovela, po prvi puta u tadašnjoj Jugoslaviji, do javne rasprave o potrebi uvođenja višestranačkog sustava.

U istraživanju javnog mnijenja građana Zagreba 1988. godine (Bahtijarević, Šiber i Zvonarević, 1989) po prvi puta je postavljeno pitanje o uvođenju višestranačkog sustava, odnosno postojanju većeg broja političkih stranaka. Bez obzira na dominantan ideologijski obrazac političke socijalizacije, većina ispitanika izjasnila se za višestranačje.

\section{Istraživanja psihologije medunacionalnih odnosa}

Budući da se radi o izrazito osjetljivom problemu tadašnjih društvenih odnosa u višenacionalnoj zajednici, sa snažnim tradicionalnim, emocionalnim, pa i ideologijskim nabojem, ne čudi da su prva istraživanja te problematike naišla na veoma burnu reakciju, čak i svojevrsnu osudu. Prvo istraživanje koje bi spadalo u ovo područje nikada nije objavljeno. Radi se o istraživanju R. Supeka krajem 50-ih godina prošlog stoljeća o problematici socijalne distance kod mladih koji su sudjelovali na radnim akcijama. ${ }^{5}$ Obrazloženje zabrane objavljivanja rezultata bilo je, naravno, ideološko: „Mi smo kroz revoluciju riješili taj problem i to treba ostaviti po strani!" Ipak, s vremenom, istraživanja su dobila svoj legitimitet, i ovdje ćemo ih, sažeto, prikazati u pet grupa problema:

\section{Oblici nacionalne vezanosti}

Nacionalni osjećaj u ovoj analizi prvenstveno se razmatra kroz koncepciju stava, znači kao latentni odnos, tendenciju prosuđivanja, vrednovanja i ponašanja u vezi $s$ fenomenom nacionalnog. Može li se odnos prema nacionalnom svesti na jedan jedinstveni odnos, na određeni kontinuum pozitivnog i negativnog? Istraživanja kod nas u to vrijeme temeljila su se na provjeri teorijskog koncepta po kome postoje određeni tipovi nacionalne vezanosti (Guetzkow, 1955), odnosno pretpostavci da se pojedinci po svojim stavovima ne distribuiraju uzduž jednog kontinuuma s obzirom na objekt stava, već da postoji nekoliko oblika vezanosti, a pojedinci se na njima grupiraju s obzirom na svoj dominantni tip odnosa.

5 Usmena informacija autora R. Supeka 
Rot i Havelka (1972, 1973) pošli su od pretpostavke o postojanju pet oblika nacionalne vezanosti $i$, slijedeći razrađenu metodologiju izrade i provjere pojedinih tvrdnji, konstruirali odgovarajuće ljestvice Likertovog tipa:

Isključiva nacionalna vezanost koju karakterizira naglašavanje vezanosti za vlastitu naciju i ocjena da je ta vezanost jedino važna i značajna. Oni smatraju da taj oblik vezanosti odgovara pojmovima etnocentrizam, odnosno nacionalni šovinizam.

Istaknuta nacionalna vezanost kod koje postoji vezanost za vlastitu naciju, ali i prihvaćanje drugih grupnih pripadnosti. To označavaju kao nacionalnu idealizaciju ili patriotizam.

Višestruka nacionalna vezanost kod koje postoji osjećaj pripadnosti vlastitoj naciji, ali i lojalnost prema međunacionalnoj suradnji i sporazumijevanju. Taj oblik zovu internacionalizam.

Istaknuta internacionalna vezanost koju karakterizira naglašavanje vezanosti za opću ljudsku zajednicu, odnosno kozmopolitizam.

Nepostojanje nacionalne vezanosti, tj. odsustvo vezanosti i pripadnosti za bilo koju naciju, što označavaju kao anacionalizam ili individualizam.

Iste, odnosno slične mjerne instrumente primijenili su i drugi autori, u prvom redu Peršič (1973), Lazaroski (1975), Đurić (1980) i Šiber (1988). Bez obzira što većina autora smatra da rezultati potvrđuju polaznu pretpostavku, ti su rezultati izrazito nekonzistentni, ponekad suprotstavljeni, postotak objašnjene varijance primjenom faktorske analize izrazito mali, a broj dobivenih faktora izrazito velik (Rot i Havelka, 1972, dobili su devet značajnih faktora od kojih analiziraju samo pet koji odgovaraju njihovom modelu!). ${ }^{6}$

\section{Stav prema nacionalnom kao dijelu ideologije}

Stav prema nacionalnoj problematici oduvijek je bio sastavni dio svih političkih pokreta bez obzira radilo se o parolama sloboda, bratstvo, jednakost, o pozivanju na krv i zemlju, odnosno prava više rase, ili bratstvo i jedinstvo. Od samog početka razvoja socijalne i političke psihologije mnogi autori su se bavili problemom može li se mnoštvo socijalnih stavova i njihova pojavna raznolikost svesti na manji broj koncepcija, i u kojim se terminima te koncepcije mogu interpretirati. Značajno mjesto u tim istraživanjima ima i stav prema nacionalnom operacionaliziran u pojmovima patriotizma i internacionalizma. Jedan od prvih istraživača tog problema Thurstone (1931) pored osnovnog faktora radikalizam - konzervativizam, uočava samo još jedan faktor: nacionalizam - internacionalizam. Ferguson (1939) kao treći izdvojeni faktor nalazi nacionalizam. U kritici postupaka, nalaza i interpretaciji tih autora Eysenck (1954) stav prema nacionalnom i internacionalnom svodi na osnovni kontinuum u domeni socijalnih stavova radikalizam - konzervativizam.

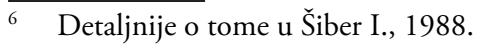


U našim je uvjetima ta problematika bila predmet triju istraživanja usmjerenih na analizu stava prema nacionalnom u kontekstu idejnih orijentacija. Osnovno je polazište tih istraživanja da ideologija predstavlja integralni sustav vrijednosti, a da stavovi teže izvjesnoj konzistentnosti i osmišljavanju odnosa pojedinca i, u ovom slučaju, političkog realiteta. Istraživanja su rađena različitim mjernim instrumentima i na različitim uzorcima, a uglavnom su došla do istih zaključaka. Radi se o istraživanjima Šibera (1974), Pantića (1977) i Jerbića i Lukić (1979). U sva tri istraživanja jasno se pokazalo postojanje jednog osnovnog idejnog faktora, mada ga autori različito imenuju. Tako Šiber tu osnovnu orijentaciju zove pro sistem anti sistem; Pantić samoupravljanje - tradicionalizam, a Jerbić i Lukić orijentacija protiv - za samoupravljanje. U okviru tog faktora nacionalna isključivost u sva tri istraživanja vezana je uz pozitivne stavove prema privatnom vlasništvu i, dijelom, uz veću religioznost. Jednako tako, u sva tri istraživanja, ustanovljen je još jedan faktor koji sadrži stav prema nacionalnom, a može ga se nazvati centralizam - decentralizam, odnosno unitarizam - nacionalna ravnopravnost.

\section{Stereotipije}

„Većinu stvari mi ne vidimo prvo, pa ih tek tada definiramo; mi ih prvo definiramo, pa ih tek tada vidimo. U bogatoj, kompleksnoj konfuziji vanjskog svijeta mi uzimamo samo ono što je naša kultura za nas već definirala i težimo da to što smo ugledali vidimo u stereotipnim formama naše kulture" (Lippman, 1961, str. 81), odnosno: „Stereotipije su tendencija da se razmišlja u rigidnim, pojednostavljenim kategorijama, u nedvosmislenim terminima crno - bijelo, pogotovo u području psihologijske i socijalne problematike“ (Stanford, 1973, str. 145). Teško da je moguće pregnantnije izraziti suštinu stereotipnog mišljenja.

Nažalost, u bivšoj Jugoslaviji, a slična je situacija i nakon uspostave samostalnih država nakon 1990. godine, postoji veoma mali broj javno publiciranih istraživanja stereotipija a uglavnom se radi o sporadičnim pokušajima koji ostaju kao dokumentacija u pojedinim institutima, s time da ih se povremeno spominje bez navođenja konkretnih rezultata. Tako, na primjer, Peršič spominje istraživanje stereotipija kod studentske omladine u Sloveniji (1975), ali ne navodi konkretne sadržaje. Rot (1975) iznosi neke podatke istraživanja stereotipija u Beogradu, ali, nažalost, više kao ilustraciju nego što daje cjelokupni prikaz. Ipak postoji niz istraživanja, istina u jednoj specifičnoj populaciji, na osnovi kojih se može zaključiti o nekim karakteristikama stereotipnog prosuđivanja. Radi se o istraživanjima Đurića (1980) koji je niz godina istraživao međunacionalne odnose, posebno stereotipije, Srba i Mađara u Vojvodini. Ograničenost njegovih podataka prvenstveno je u tome što su obuhvaćene samo dvije nacionalne skupine i što su istraživanja provedena pretežno na djeci i omladini. Ipak, po svojoj temeljitosti i sveobuhvatnosti ova su istraživanja primjer kako provoditi takva istraživanja i 
obavljati relevantne analize podataka. Osnovni nalazi autora odnose se na auto stereotipije i hetero stereotipije Srba i Mađara, na sadržaje stereotipija, sličnost stereotipija roditelja i djece, kao i promjene sadržaja tijekom vremena.

\section{Socijalna distanca}

U svakodnevnom životu ljudi, bilo svojom vlastitom željom, bilo stjecajem okolnosti, stupaju u različite odnose s drugim ljudima, odnose koji imaju različiti stupanj značenja, trajnosti i emocionalne zasićenosti za pojedinca. Te potencijalne odnose s pripadnicima drugih društvenih grupa, kao i odnos pojedinca prema tim odnosima, Park (1924) je obuhvatio pojmom socijalne distance pod čime podrazumijeva stupnjeve razumijevanja i intimnosti što općenito obilježavaju socijalne odnose. Ovo Parkovo shvaćanje operacionalizirao je Bogardus (1925) u obliku konkretnog mjernog instrumenta kao ljestvicu socijalne distance.

Istraživanja socijalne distance početak su istraživanja međunacionalnih odnosa kod nas. O prva dva istraživanja ne raspolažemo izvornim podacima, izuzevši usputnog navođenja nekih nalaza u drugim radovima tih autora. Već spomenuto istraživanje Supeka (1963) ponovljeno u narednim godinama (1958-1961), objavljeno je u knjizi Psihosociologija radne akcije. Sljedeće je istraživanje Rota (1963-1966). ${ }^{7}$ Prvo istraživanje koje je obuhvatilo cjelokupnu jugoslavensku populaciju je istraživanje Pantića (1967). Ispitivana je socijalna distanca prema pojedinim nacionalnim skupinama u tadašnjoj Jugoslaviji. Opći nalaz je da je 59\% ispitanika bez distance, 28\% imali su slabu distancu, a jaku distancu prema drugima imalo je $13 \%$ ispitanika. Ponovljeno istraživanje 1985. godine pokazalo je uglavnom slične rezultate. ${ }^{8}$ Istraživanje Jerbića i Lukić (1979) provedeno na mladima u Hrvatskoj također pokazuje da oko 61\% mladih uopće nema distancu prema drugima, a da $14 \%$ iskazuje izrazitu distancu. Posljednje istraživanje u tom razdoblju provedeno 1987. godine ${ }^{9}$ pokazuje dramatične promjene. Izrazito jaku socijalnu distancu iskazuje u rasponu od 22\% ispitanika u Hrvatskoj do 54\% ispitanika na Kosovu! Nema nikakve sumnje da su ti rezultati odraz tadašnjih političkih prilika. Ipak, treba napomenuti da takvu razinu socijalne distance pokazuju i istraživanja provedena u SAD-u.

\section{Javno mnijenje}

Istraživanja javnog mnijenja prije društvenih promjena bila su na marginama društvenog interesa, posvećivala im se minimalna pozornost i više su bila slučajna

\footnotetext{
Nažalost, do samog izvještaja nismo mogli doći. Ovo navodimo na temelju sekundarnih izvora: N. Rot (1972), i D. Pantić (1967)

8 Grupa autora, Beograd (1986).

9 Grupa autora, Ljubljana (1988).
} 
pojava nego trajan društveni interes. ${ }^{10}$ Najveći broj istraživanja zahvatio je problem mnijenja o međunacionalnim odnosima na osnovi percepcije problema koji zahtijevaju najveću pozornost društva. Iz ponuđenih lista ispitanik je birao ona dva koja su, po njegovom mišljenju, najznačajnija. Od prvog takvog istraživanja Džinića (1965), Zvonarevića i sur. (1969), Magdalenića (1969), Šibera (1974), do istraživanja na Fakultetu političkih znanosti (1982), pokazuje se stabilan broj ispitanika (od 10.9\% do 12.7\%) koji smatraju da je problematika međunacionalnih odnosa dominantna u tadašnjem jugoslavenskom društvu. Interesantan je nalaz istraživanja Zvonarevića i sur. (1971) o međunacionalnim odnosima u Hrvatskoj po kome svega $2.9 \%$ ispitanika smatra da treba ograničiti utjecaj Hrvata, a 7.3\% smatra da treba ograničiti utjecaj Srba. Ovdje, kao uostalom i kod svih ostalih rezultata, treba naglasiti vjerojatan utjecaj samocenzure i konformizma imajući u vidu prirodu tadašnjega političkog sustava.

\section{Istraživanja osobina ličnosti i karakteristika društvenih grupa}

Budući da se ovdje radi o prikazu razvoja političke psihologije, zadržat ćemo se samo na onim psihologijskim sadržajima koji su izrazito povezani s fenomenom politike. To su u prvom redu problemi autoritarnosti i političke kulture.

\section{Autoritarna ličnost}

Autoritarnošću se označava sindrom psihologijskih osobina povezanih s antidemokratskom orijentacijom, pojavama etnocentrizma i konzervativizma. Autoritarna ličnost je ona koja traži autoritet kome bi vjerovala, koji bi joj pružio sigurnost i izvjesnost, a istodobno je spremna da se na isti način postavi prema onima koji o njoj ovise, da inzistira na svom autoritetu i hijerarhiji. Živeći i socijalizirajući se u okviru autoritarnih odnosa unutar obitelji, religije, države, pojedinac traži sigurnost u ocu, Bogu ili vlasti. U situacijama društvene krize, nesigurnosti, gubitka perspektive, pojedinac traži „oca domovine“, „vođu“ ili „mesiju“. Upravo takav, autoritaran, prevladavajući karakter zahvalno je psihološko tlo za razne oblike manipulacije, a pogotovo za homogenizaciju unutar grupe i za izražavanje agresivnosti prema vanjskim grupama. Drugim riječima, predrasude su sastavni dio takvog karaktera, a samo od vanjskih okolnosti (krize, frustracije) ovisi njihovo izražavanje. Dakako da svaka frustracija ne dovodi do agresivnog ponašanja, kao što ni svaka „manjinska grupa “ nije objekt predrasuda. Također, sama autoritarnost nije neminovno uzrok proganjanja drugih. Tu se radi isključivo o psihološkim pretpostavkama i mehanizmima koji posreduju u odredenoj situaciji, koji olakšavaju

$\overline{10}$ Izuzetak je Centar za istraživanje javnog mnijenja pri Fakultetu za družbene vede u Ljubljani, dok su odgovarajući instituti u Zagrebu i Beogradu imali samo sporadična istraživanja. 
određeno ponašanje i uvjetuju njegov intenzitet. Taj odnos strukture ličnosti i dominantnog obrasca političkih odnosa i ponašanja dovodi do postavljanja nekoliko relevantnih pitanja koja, $s$ psihologijskog aspekta, mogu pružiti dodatne spoznaje u razumijevanju prirode političkog procesa u nekom društvu:

- Do koje je mjere autoritarnost, kao agregatna osobina populacije, prisutna u strukturi ličnosti, pa prema tome i zahvalna osnova različitih oblika manipulacija, autoritarnih rješenja i zapreka razvoju demokracije?

- U kojim segmentima populacije je ta osobina ličnosti osobito prisutna?

- Čime je autoritarnost uvjetovana, odnosno, radi li se o ego obrambenoj ili kognitivnoj autoritarnosti?

- Kakva je povezanost autoritarne strukture ličnosti i prihvaćanja određenih idejnih orijentacija?

$\mathrm{Na}$ ta pitanja je teško odgovoriti na temelju ranijih istraživanja budući da je problem autoritarnosti bio uglavnom sporedna varijabla, a i samih istraživanja ima vrlo malo.

Rot i Havelka (1973) istražuju sindrom autoritarnosti i njegovu povezanost $s$ etnocentrizmom. Uz minimalne izmjene i dopune primijenili su poznatu Fljestvicu (Adorno i dr., 1950) na uzorku učenika srednjih škola u Beogradu i Kragujevcu. Tri su osnovna nalaza relevantna za ovaj prikaz.

Prvo, dobiveni rezultati razine autoritarnosti izrazito su visoki, a kod učenica industrijskih škola dobiven je najviši rezultat do tada zabilježen u literaturi (Rot i Havelka, 1973).

Drugo, dobivena je veza između autoritarnosti, osobina pojedinca i socijalne okoline. Učenici iz Beograda imali su nižu autoritarnost od učenika iz Kragujevca, učenici gimnazija nižu autoritarnost od učenika industrijskih škola, mladići nižu autoritarnost od djevojaka. Isto tako pokazalo se je da je razina autoritarnosti negativno povezana s obrazovanjem roditelja.

Tré́e, dobivena je izrazita povezanost (korelacija 0.54) između autoritarnosti i isključive nacionalne vezanosti (koju oni izjednačavaju s etnocentrizmom). Slični rezultati, ali niži, dobiveni su i u odnosu autoritarnosti i socijalne distance prema drugim narodima.

U veoma složenoj metodološko-statističkoj analizi Jerbić i Lukić (1979) su, na uzorku srednjoškolaca u Hrvatskoj, pored ostalog, zahvatili i odnos autoritarnosti i određenih vrijednosnih orijentacija. Dobivena je negativna povezanost autoritarnosti sa socijalističkim samoupravljanjem $(-0.255)$, a pozitivna sa socijalnom distancom prema drugim narodima (0.284) is etnocentrizmom (0.404).

U istraživanju na tadašnjim članovima Saveza komunista (SK) (Šiber, 1984) dobivena je povezanost autoritarnosti s idejnom nekritičnosti (0.482) kao i negativan odnos prema samoupravljanju (-0.400). 
U ambicioznom istraživanju na cjelini tadašnjeg jugoslavenskog prostora čiji rezultati, nažalost, nisu nikada u cijelosti objavljeni, ${ }^{11}$ pokazalo se da nema bitnih razlika u razini autoritarnosti između pojedinih republika i pokrajina.

Bez obzira na nedostatak većeg broja istraživanja i na njihovu relativnu marginalnost, mislimo da se može ponoviti zaključak koji je sadržan u radu koji prikazuje opširnije tu problematiku (Šiber, 1989): „Opći zaključak do kojeg dolazimo na temelju navedenih nalaza jest da izrazita prisutnost autoritarnosti u psihološkoj strukturi naše populacije predstavlja realnu pretpostavku nametanja različitih utjecaja, pogotovo u situacijama društvenih previranja, nesigurnosti i konflikata“.

\section{Politička kultura}

Pojam političke kulture uvode Almond i Verba (1963) kako bi pokušali objasniti, u okviru komparativne politike, zašto dolazi do različite učinkovitosti demokratskih procesa u zemljama koje imaju sličan ustavno-pravni poredak. Odgovor nalaze u različitim političkim kulturama uvjetovanim povijesnim procesima. Po njihovom mišljenju: „Pojam političke kulture odnosi se na političke orijentacije - prema političkom sustavu i njegovim različitim dijelovima, kao i stavove prema ulozi pojedinca u sustavu“. Drugim riječima, pod političkom kulturom podrazumijevaju niz psiholoških osobina koje su dominantne u nekom društvu. Pojam je sličan pojmu društvenog karaktera, $s$ time da se ograničava na područje političkog ponašanja. Po njima ta orijentacija označava internalizirane aspekte objekata i odnosa. To uključuje:

- Kognitivnu orijentaciju - znanje i vjerovanje o političkom sustavu, njegovoj ulozi i zahtjevima tih uloga, ulaganjima u sustav i njegovim rezultatima;

- Afektivnu orijentaciju ili osjećaje o političkom sustavu, njegovoj ulozi, osobama i učincima;

- Evaluativnu orijentaciju, odnosno prosuđivanje i mišljenje o političkim objektima koji tipično uključuju kombinaciju vrijednosnih standarda i kriterija s informacijom i osjećajima.

Kolika je važnost političke kulture za funkcioniranje demokratskog društva najbolje se vidi iz često citirane misli Dahrendorfa (1992) u vezi promjena u zemljama Istočne Europe: „Politički sustav moguće je promijeniti za 6 mjeseci; za promjenu ekonomskog sustava potrebno je 6 godina; za izgradnju demokratske političke kulture treba 60 godina“.

Teško je jednoznačno odrediti konkretna istraživanja koja bi se usredotočila na kompleksnost takvog sadržaja, ali se mnoga istraživanja mogu interpretirati u okviru toga koncepta. Za potrebe ovog prikaza i ilustraciju teze da su i prije

${ }_{11}$ Radi se o projektu „Klasno biće jugoslavenskog društva“ koje je provedeno 1986. godine na reprezentativnim uzorcima svih republika i pokrajina. Rukovodilac istraživanja bio je Fakultet za družbene vede u Ljubljani pod vodstvom Nike Toša. 
političkih promjena 90 -ih godina prošlog stoljeća naši istraživači bili u trendu razvoja suvremene znanosti možemo navesti istraživanje Novosela (1969) koncem 60-ih godina prošlog stoljeća u Hrvatskoj i analizu Benca (1970). Primijenivši originalni upitnik Almonda i Verbe (1963) na uzorku punoljetnog stanovništva, Novosel je dobio rezultate koji su ukazivali na prevladavajuće oblike parohijalne političke kulture, odnosno na činjenicu da je težište na pripadnosti određenoj zajednici (nacionalnoj, vjerskoj i sl.) iz čega proizlaze prava i obaveze pojedinca i podaničke političke kulture koja se sastoji u bespogovornom prihvaćanju autoriteta i političkoj pasivnosti, dok je participativna politička kultura koja se sastoji u aktivnom odnosu pojedinca kako prema politici tako i prema ostalim socijalnim procesima, bila samo u naznakama. ${ }^{12} \mathrm{M}$. Benc analizirao je pojedine aspekte političke kulture na temelju dvaju anketnih istraživanja i sustavne analize ponašanja birača na pojedina pitanja na temelju zapažanja anketara.

\section{Radovi iz područja političke psihologije - poslije 1990.}

Promjena političkog poretka i demokratski, višestranački izbori, postavili su nove probleme pa time i nove mogućnosti pred istraživače. $S$ jedne strane, izbor pojedine političke opcije omogućava korištenje one ključne kriterijske varijable koja je temelj suvremene politike - izbor određene političke opcije, a s druge, istraživanja problema koji su u ranijem sustavu bili potiskivani, pa i zabranjivani. Pri tome ne treba gubiti iz vida da se problematika političke psihologije vrlo široko upotrebljava za potrebe same političke prakse. Tu bi na neki način mogli reći da isto tako kako se ponekad politologija određuje kao tehnologija moći, tako se i politička psihologija do neke mjere može odrediti kao sadržaj $i$ mehanizmi te tehnologije. ${ }^{13}$

Budući da su istraživanja nakon 1990. uglavnom kompleksna i obuhvaćaju veći broj problema, fenomena i njihov međusobni odnos, teško ih je tematski prikazati kao što je to učinjeno ranije. Isto tako treba imati u vidu da višestranačka demokracija otvara niz problema koji su bili ili irelevantni ili nedostupni za istraživanje u ranijem razdoblju.

\section{Istraživanje izbora i ponašanja birača}

Uvođenjem višestranačkog sustava suočili smo se s dva na prvi pogled jednostavna pitanja:

12 Bilo bi interesantno ponoviti to istraživanje nakon skoro 50 godina i nakon 25 godina promjene političkog sustava.

13 Veliki dio problematike političkog marketinga temelji se na spoznajama političke psihologije od istraživanja javnog mnijenja (opredjeljenja biračkog tijela, istraživanja političke motivacije, struktura potreba, ideologijskih profila pojedinih skupina birača i sl.), do problematike političke komunikacije (oglašavanja, izbornih slogana, političkih nastupa), kao i predviđanja izbornih rezultata. 
- zašto ljudi izlaze ili ne izlaze na izbore,

- kome i zašto daju svoj glas, odnosno stranačko opredjeljenje.

Odgovori na ta pitanja postaju ključne varijable razumijevanja uspostavljanja nositelja vlasti. $U$ pokušaju davanja odgovora, ili, drugim riječima, analizi svih relevantnih varijabli koje utječu na te odluke, na djelu je čitava povijest jednog naroda (imajući u vidu prije svega povijesne rascjepe koji su u temelju dugotrajnih dispozicija izbornog ponašanja), njegova socijalna i ekonomska struktura (do koje je mjere čovjek politički ono što je socijalno), politička kultura, proces socijalizacije i utjecaj socijalne okoline u kojoj se pojedinac nalazi, utjecaj vrste rješenja izbornog i stranačkog sustava, mobilizacijska uloga političkih stranaka, uloga masovnih medija i njihovo posredovanje, struktura aktualnih problema u zemlji i relevantnom okruženju i njihova percepcija itd. Kao što vidimo, tu je niz problema koji omogućavaju i zahtijevaju i psihologijsku analizu, ali svakako u suradnji, prije svega, politologijskih i sociologijskih pristupa.

U samom početku u Hrvatskoj možemo pratiti dvije grupe istraživača. To su istraživači na Fakultetu političkih znanosti u okviru dugoročnog projekta Izbori, stranke i parlament u Hrvatskoj te istraživači s Instituta „Ivo Pilar“. Obje grupe istraživača objavile su niz relevantnih knjiga i članaka. Autori s Fakulteta političkih znanosti objavili su do sada desetak knjiga neposredno iz problematike izbora i oko 50 radova u časopisima, od čega dvadesetak u inozemstvu, dok su radovi suradnika Instituta „Ivo Pilar" objavljivani uglavnom u časopisu Društvena istraživanja. ${ }^{14}$

Znanstveni problemi obrađivani u tim istraživanjima nesumnjivo pokazuju da danas u Hrvatskoj raspolažemo mnogim spoznajama o ponašanju birača, njihovoj motivacijskoj osnovi, vrijednosnim opredjeljenjima i slično.

\section{Razlozi izlaska na izbore}

Sudjelovanje u političkim procesima, prije svega u procesima konstituiranja predstavničkih tijela, ključna je pretpostavka demokratskog društva. Izaći na izbore ili ne, odnosno, zašto izaći ili ne, temeljno je pitanje motivacije građana u izbornim procesima. Psihološka analiza zahtijeva razumijevanje i osobe i psihološkog svijeta koji je okružuje, ili, kako to kaže Lewin (1951): „Ponašanje ovisi o položaju osobe i njezine okoline. Da bi se ponašanje razumjelo ili predvidjelo, osoba i njezina okolina moraju se razmatrati kao konstelacija međusobnih činilaca". Običan statistički podatak o manjoj izbornoj participaciji žena, tj. odnos jedne demografske varijable (spola) i političke aktivnosti, sadržava i socijalno-psihološke kategorije društveno-ekonomskog položaja žena i kulturnih obrazaca danog društva.

Analiza izlaska građana na izbore nakon promjene političkog sustava pokazuje izrazitu ulogu percepcije važnosti izbora za društvo kao i neizvjesnost izbornih

$\overline{14}$ Pored niza pojedinačnih istraživanja, sustavno i longitudinalno izborni procesi prate se od 1990. godine samo na Fakultetu političkih znanosti. 
rezultata (Šiber, 2005). Ipak, kako to naglašava Campbell (1962), pravi je pasivni građanin onaj koji ne glasa zbog nedostatka motivacije. Za razumijevanje političke motivacije možemo primijeniti poznatu postavku Vroomove teorije očekivanja po kojoj „Motivacijska sila izborne situacije je proporcionalna percipiranoj mogućnosti da će izbor jedne a ne neke druge opcije dovesti do željenog rezultata“. U ovom prikazu zadržat ćemo se na dva istraživanja. Jedno je istraživanje Lamze Posavec (2004) koja se bavi izbornom apstinencijom, a drugo Šibera (2005) koje je usmjereno razlozima izbornog opredjeljenja.

Osnovni cilj prvog istraživanja (Lamza Posavec, 2004) je provjera pretpostavke da se osobe koje ne namjeravaju izaći na izbore razlikuju prema demografskim i socijalnim osobinama, političkim stavovima i općenito interesom za politiku, od osoba koje izlaze na izbore. Analiza demografskih i socijalnih osobina ispitanika pokazala je, mada ponekad statistički značajne, ipak vrlo male povezanosti s izbornom apstinencijom. Znatno veći utjecaj ima opća politička nezainteresiranost, nezadovoljstvo ispunjavanjem izbornih obećanja kao i percepcija da promjena nositelja vlasti neće dovesti do željenih promjena.

Drugo istraživanje (Šiber, 2005) došlo je do istih rezultata, uz jednu značajnu nadopunu. Naime, usporedo s razlozima neizlaska, tražili su se i razlozi sudjelovanja u izborima. Primjenom faktorske analize dobivena su tri značajna i interpretabilna faktora: jedan je nazvan nezainteresiranost i osjećaj bespomoćnosti, drugi ideologijska isključivost, a treći politička odgovornost. Za hrvatsku političku zbilju izrazito je značajan drugi faktor koji u osnovi sadrži želju da se svojim glasom spriječi politički suparnik (HDZ ili SDP) da dođe na vlast! Uostalom, odnos tog faktora i opredjeljenja za pojedinu stranku je 0.67 (eta koeficijent) na izborima 2.000. godine, odnosno 0.76 na izborima 2003. godine.

Još jedan zanimljiv nalaz je iz istraživanja Rimca (1999), koji istražuje osnovne psihološke odrednice formiranja političke participacije i nalazi da nema značajnije empirijske potvrde o većoj složenosti izbornog opredjeljenja kod kognitivno opremljenijih osoba.

\section{Stranačko opredjeljenje}

Osnovni nalazi dosadašnjih istraživanja kome i zašto ljudi daju svoj glas, odnosno o razlozima stranačkog opredjeljenja birača, mogli bi se, vrlo sažeto, analizirati $u$ tri grupe problema.

Interesno ideologijski. Radi se o poznatim postavkama po kojima je čovjek politički ono što je socijalno. U razvoju građanskog društva, prije svega 19. stoljeća, dolazi do sukoba rada i kapitala i na tome se temelje određeni svjetonazori i političko profiliranje stranaka. ${ }^{15}$ Klasni, ali i religijski rascjepi oblikovali su izborni

15 Sukob rada i kapitala samo je jedan od rascjepa na kojima se temelji formiranje političkog opredjeljenja. Prema teoriji rascjepa (Lipset Rokkan, 1960) ostali su: centar - periferija; država - crkva, i selo - grad. 
diskurs u zapadnim demokracijama. Kako to kaže Dalton (1996): „Socijalno demokratske stranke okreću se radu i radnicima, dok kršćansko demokratske regrutiraju svoju podršku iz posjetitelja nedjeljnih misa“.

Tradicionalno ideologijski. Jednom kada su formirane stranačke identifikacije, bilo na temelju egzistencijalnih uvjeta života, bilo na temelju traumatskog iskustva, one traju i nakon promjene socioekonomskog položaja, odnosno nakon što je neki povijesni događaj prevladan. Ovdje se radi o rezultatima političke socijalizacije, prije svega u okviru obitelji, odnosno, kako to određuju Lippset i Rokkan (1960) u već spomenutom radu, radi se o svojevrsnoj teoriji zaledivanja, odnosno o generacijskom prenošenju određenih opredjeljenja.

Usmjerenost na konkretne probleme. Ne postoji snažna stranačka identifikacija već se birač opredjeljuje na temelju konkretnog programa za rješavanje nekog problema koji je za njega važan i zaokuplja njegovu pozornost.

Kao što vidimo, sve tri motivacijske osnove su izrazito psihološki zasićene. Radi se o zajedničkim potrebama i interesima pojedinih socijalnih skupina koje proizlaze iz njihovog socioekonomskog položaja; o procesu socijalizacije, prije svega u obiteljskoj sredini, u kojoj se stvara stranački identitet. Razvojem društva, smanjivanjem socijalnih sukoba (prije svega zbog prirode rada, razvoja tehnologije i usluga, što razbija raniju dihotomiju rada i kapitala), pojedinac se sve više okreće problemima svakodnevnog života što postaje temelj njegovog političkog odabira.

Što su pokazali rezultati dosadašnjih istraživanja u Hrvatskoj? Od prvih demokratskih izbora 1990. godine do danas, socijalna uvjetovanost političkog opredjeljenja je zanemariva. ${ }^{16}$ Mogu se uočiti manje razlike u opredjeljenju s obzirom na razinu obrazovanja (manje obrazovani - desno, više obrazovani - lijevo) i mjesto boravka (selo - desno, grad - lijevo), što je svakako nedostatno za potpuno razumijevanje izbornih rezultata. Opredjeljivanje na temelju konkretnih stranačkih politika (obrazovanje, zdravstvo, mirovinski sustav, vanjska politika, zaštita okoliša i sl.) također se pokazuje beznačajnim za razumijevanje izbornog ponašanja. ${ }^{17}$

Prema dosadašnjim istraživanjima ${ }^{18}$ odlučujuće varijable za razumijevanje stranačkog opredjeljenja su tradicionalno - ideologijske, odnosno povijesni rascjep u Hrvatskoj u Drugom svjetskom ratu i religioznost.

Dramatični događaji u povijesti naroda ostavljaju trajne posljedice u svijesti budućih generacija i, na neki način, predstavljaju međaš u razumijevanju latentnih i manifestnih sukoba. Posebno su značajni masovni sukobi unutar nekog naroda

$\overline{16}$ Ovaj prikaz temelji se na rezultatima longitudinalnih istraživanja na Fakultetu političkih znanosti u Zagrebu.

17 Na takvim problemima se tek u zadnje vrijeme formiraju nove stranke, tzv. one issue party, kao što su Živi zid, Orah, sl.

18 Navodimo samo neka: Grdešić, I. i dr. Hrvatska u izborima; Kasapović, Šiber, Zakošek, Birači i demokracija. U: Kasapović, M. (ur.),Hrvatska politika 1990- 2000; Siber, I. (2007). Političko ponašanje - istraživanja hrvatskog društva. 
koji imaju obilježja građanskog rata. Francuska revolucija, koja se u europskoj političkoj misli smatra početkom suvremene političke povijesti, predstavljala je veliki, krvavi sukob različitih političkih ideja i staleža, ali i različitih regija tadašnjega francuskog društva. Sudjelovanje pojedinih članova obitelji u tom sukobu prije više od dva stoljeća i danas, u stanovitoj mjeri, utječe na politička usmjerenja i izbor stranaka pripadnika tih obitelji (Todd, 1988). Građanski rat u SAD-u, sukob Sjevera i Juga, koji se smatra početkom suvremene povijesti te zemlje (Janda, Berry and Goldman, 1989), također je utjecao na određene „rascjepe " u političkim opredjeljenjima. Ta su zbivanja, doduše, u suvremenim uvjetima izgubila emocionalni naboj i sadržaj koji je bio uzrok sukoba, ali je ostala obiteljska tradicija, svojevrsna vjernost i uspomena koja se prenosi s koljena na koljeno. Miller (1976) upotrebljava metaforu kako bi objasnio stranačku lojalnost: politika je analogna religiji, a birač je analogan religijskom sljedbeniku.

Na hrvatskim prostorima takvo 'traumatsko' značenje imala su, i imaju, zbivanja tijekom Drugoga svjetskog rata. Vjerojatno ne postoji zemlja i narod (s izuzetkom Španjolske) u kojoj je unutarnji sukob bio tako vehementan i koji je bio vođen $s$ tako različitim opredjeljenjima i posljedicama. Ne ulazeći u različite razloge političkih opredjeljenja (i njihovu kritiku ili opravdanje) kao što su želja za uspostavom nacionalne države, snažni revanšizam uz prihvaćanje i provođenje rasnih zakona, konformizam, građanska poslušnost i odziv na mobilizaciju NDHa; otpor zločinima i talijanskoj okupaciji hrvatskog teritorija, šansa za ostvarenje komunističkog poretka, a s vremenom i svijest o NDH kao gubitničkoj strani, mobilizacija nakon pada Italije i sl. među pristašama partizanskog pokreta, i danas, poslije više od 70 godina, ta se opredjeljenja sve više svode na dvije suprotstavljene $\mathrm{i}$ isključive opcije. Aktivnih sudionika tog sukoba uglavnom više nema, ali su još uvijek prisutni snažni emocionalni naboji stečeni procesom socijalizacije (teorija zamrzavanja) koji dovode do uzajamne diskvalifikacije. Rezultati istraživanja pokazuju (Šiber, 1998, 2007) da upravo politička biografija obitelji formirana na tom povijesnom rascjepu u najvećoj mjeri određuje političko opredjeljenje novih generacija, ili, kako to kaže Marx (1953): „mrtvi iz grobova vuku žive“, odnosno „mrtvi kao mora pritišću mozak živih“! Sažeto, birači NDH tradicije biraju u omjeru četiri naprema jedan stranke desnice, a birači NOB tradicije četiri naprema jedan stranke ljevice!

Pored političke biografije obitelji, varijabla koja značajno djeluje na političko opredjeljenje je i religioznost. Ona je povezana kako s određenim političkim svjetonazorom - veća religioznost $s$ konzervativnijim svjetonazorom, a manja $s$ liberalnijim - tako i s određenom strukturom socijalnih i političkih stavova. Stoga je poznavanje stupnja i vrste religioznosti (jedna od podjela razlikuje uvjerene $\mathrm{i}$ tradicionalne vjernike), vrlo važno za političko profiliranje stranaka i njihovo djelovanje. Neke stranke ekspliciraju svoja religijska opredjeljenja, poput demokršćanskih stranaka, dok su neke na glasu kao ateističke stranke. Ključni nalaz 
niza istraživanja na Fakultetu političkih znanosti (Šiber, 2007) jest da su se nakon 1990. izrazito promijenili iskazi građana o njihovoj religioznosti - 1990. godine $47 \%$ je izjavljivalo da nisu vjernici, a 2003. samo $14 \%$ ! Ono što je značajno je činjenica da u Sloveniji, koja je bila u istom političkom sustavu kao i Hrvatska, do takvih promjena nije došlo (Toš, 1999). To znači da su promjenama u iskazivanju religioznosti umnogome pridonijeli konkretni procesi u pojedinim državama, a ne mogućnost slobodnog iznošenja svojih opredjeljenja.

\section{Struktura političkih stavova, osobine ličnosti i stranačko opredjeljenje}

Mogućnosti koje su se otvorile uvođenjem višestranačke demokracije potaknule su veći broj istraživanja odnosa pojedinih osobina ličnosti i izbora određenih političkih opcija, odnosno političkih stavova. U svom radu o strukturiranju hrvatske stranačke scene Šiber (1993), na temelju istraživanja birača o tome s kime bi njihov stranački izbor trebao koalirati, nalazi tri izrazito unutar sebe povezana grozda, koji odgovaraju tradicionalnoj podjeli na ljevicu, centar i desnicu, s time da se izvan tih skupina nalaze regionalne stranke i stranke manjina.

Sličan nalaz dobili su i Milas i Rimac, (1994) koji, analizirajući stavove prema pojedinim strankama u Hrvatskoj, zaključuju da se hrvatski politički prostor može analizirati na temelju četiri latentne dimenzije koje sadržavaju desnicu, centar, ljevicu i regionalne stranke. Našli su pozitivan odnos desnih stranaka i centra i, nešto manje, pozitivan odnos lijevih stranaka i regionalnih. ${ }^{19}$

$\mathrm{U}$ analizi političkih stavova i stranačkog opredjeljenja uglavnom postoje $d v a$ pristupa:

- Prvi pristup uzima jednostavnu $L-D$ (lijevo - desno) ljestvicu kao pokazatelj osnovne ideologijske orijentacije,

- drugi se sastoji u analizi niza konkretnih stavova prema određenim politički relevantnim pojavama i primjenom faktorske analize pokušava ustanoviti određeni broj latentnih dimenzija i njihov odnos s izborom određene političke opcije.

L - D dimenzija osobne samoidentifikacije na, uobičajeno, ljestvici od 1 (krajnja ljevica) do 10 (krajnja desnica), kako rezultati niza istraživanja pokazuju, jednostavna je za primjenu, razumljiva ispitanicima, i, što je najvažnije, visoko povezana s izborom određene političke stranke (Šiber, 1993, Rimac, 1999). Značenje lijevog i desnog, koje je biračima samorazumljivo, još uvijek ništa ne govori o samom sadržaju, odnosno o konkretnim stavovima njihovog opredjeljenja, pa prema tome i sukladnosti tih opredjeljenja programima i djelovanju političkih stranaka. Nekoliko istraživanja bavilo se tom problematikom, većinom u okviru svojih doktorskih disertacija.

19 Ovo istraživanje pokazuje kako su rezultati ovisni o konkretnoj situaciji u određenom vremenu. S pojavom HDSSB-a ta veza između lijevih i regionalnih stranaka svakako je različita. 
Rimac (1999) u svojoj doktorskoj disertaciji na temelju primjene upitnika Eysencka $(1944,1954)$ dobiva dosta heterogenu faktorsku strukturu ${ }^{20} \mathrm{i}$, sukladno tome, slabu povezanost $s$ izbornim opredjeljenjima.

Milas (1998) u svojoj doktorskoj disertaciji, također primjenom Eysenck-ova upitnika, istražuje odnos društvenih stavova, ličnosti i društvene poželjnosti. U kompleksnom metodološkom nacrtu koji dijelom uključuje i eksperimentalnu provjeru (na dvije grupe ispitanika dati su različiti uvodni naputci) dobivena su tri osnovna nalaza. Prvo, primjenom faktorske analize dobivena su tri temeljna faktora: religioznost, kozmopolitizam i spolne slobode (ti sadržaji većinom se interpretiraju na dimenziji tradicionalizam - modernizam); drugo, povezanost osobina ličnosti i društvenih stavova je značajna, odnosno osobine ličnosti objašnjavaju $20 \%$ do $30 \%$ varijance stavova; tréé, na prihvaćanje određenih društvenih stavova utječu socijalni faktori, odnosno psihoticizam i društvena poželjnost.

Šiber (2007) faktorskom analizom ljestvica političkih stavova dobiva dva faktora. Prvi faktor, liberalno-poduzetnički - etatističko-egalitarni, koji stavlja težište na socijalnu sigurnost radnika, svojevrsnu 'uravnilovku', sudjelovanje u odlučivanju i jaku ulogu države; odnosno, tvrdnje koje sadrže zalaganje za privatno vlasništvo, poduzetništvo i što manju državnu regulativu. Drugi faktor, modernističko tradicionalni, dobiven je faktorskom analizom drugog reda i sadrži religioznost, odnos crkve i države, odnos prema tradiciji, autoritetu, odnos prema manjinama i ženama, i autoritarnost. Taj generalni faktor objašnjava $45 \%$ ukupne varijance. $\mathrm{Na}$ tako dobivenom dvodimenzionalnom stranačkom prostoru pokazalo se je da je prvi faktor slabo diskriminativan, a da su izrazite razlike između birača različitih stranaka na dimenziji modernističko - tradicionalno.

Blanuša (2009) u svojoj doktorskoj disertaciji analizira s jedne strane napise između 1980. i 2007. koji se odnose na teorije zavjere, a s druge strane stavove građana o tim problemima. Pokazao je postojanje dva tipa hrvatskih političkih teorija zavjera - 'zavjere vlasti u 90-ima' i 'zavjere unutarnjih i vanjskih neprijatelja'. Statističkim analizama pokazuje kinički karakter prvog, odnosno 'cinički' karakter drugog tipa zavjere. Prvi tip predstavlja podršku demokratskom poretku kao specifična kritika vlasti, a drugi je povezan $s$ autoritarnim tendencijama koje podržavaju mentalitet opsadnog stanja. Prvi tip podržavaju građani socijaldemokratskog i liberalnog svjetonazora, a drugi građani nacionalističkog i konzervativnog svjetonazora. Isto tako pokazala se i povezanost s političkom biografijom obitelji. Isti autor u daljnjim istraživanjima utvrđuje povezanost konspirativnog mišljenja, ideoloških rascjepa i političkih biografija (Blanuša, 2013), zatim političke biografije kao izvora suprotstavljenih sjećanja i osnove za transgeneracijsku traumu (Blanuša, 2015), te načinima tabuizacije traumatskih događaja i procesa (Blanuša, 2017).

$\overline{20}$ Razlog tome je svakako upitnik koji je formuliran u drugom vremenu i prostoru tako da nije bio primjeren situaciji naše zemlje. 
Šram (2007) u svojoj doktorskoj disertaciji radi komparativnu analizu zagrebačkih i beogradskih studenata s obzirom na društveni karakter, političku kulturu i strukturu ličnosti. Konkretnije, istražuje nacionalnu svijest, ideologiju, alijenaciju i vrijednosne orijentacije. Analiza pojedinih varijabli i njihov međuodnos pokazuju da nacionalizam i sociopatija idu zajedno, odnosno postojanje povezanosti između nacionalističkog sentimenta, desne autoritarnosti i agresivne strukture ličnosti koja je neovisna o sociokulturnom kontekstu. Najveću razliku među uzorcima nalazi u dimenziji koju definira kao nacionalno opsadno stanje koja je izraženija kod beogradskih studenata.

Bovan (2017), za razliku od prethodnih istraživanja, u svojoj disertaciji radi strogo eksperimentalni nacrt istraživanja - pokušava analizirati koncept točnog glasovanja. Pod time podrazumijeva sukladnost stavova pojedinca i programa političkih stranaka. Budući da se radi o eksperimentalnom nacrtu istraživanja nisu korišteni stvarni nazivi stranaka već su uzeti sadržaji za koje se pretpostavlja da su karakteristični za pojedine stranke u okviru političkog prostora. Isti autor (Bovan, Banai i Banai, 2016) bavi se također istraživanjem prognostičke važnosti vokalnih karakteristika kandidata na vjerojatnost da će građani za njih glasati.

Problem koji je uvijek prisutan u istraživanju odnosa osobina ličnosti i stranačkog opredjeljenja svakako je odnos autoritarnosti, odnosno moguće razlike u toj osobini ličnosti u biračkim tijelima različitih stranaka. U preglednom istraživanju Meloen Farner and German(1994) pokazalo se, bez izuzetka, da što je stranka desnijeg usmjerenja raste i autoritarnost njenog biračkog tijela. Ta se zakonitost pokazala i u Hrvatskoj (Šiber, 2007).

Neovisno o samom političkom ponašanju, odnosno stranačkom opredjeljenju, postoji niz istraživanja autoritarnosti relevantnih za političku psihologiju. Ovdje ćemo navesti samo neka: mjerne karakteristike ljestvice autoritarnosti (Radin, Kregar, Magdalenić, Petković i Rimac, 1990); autoritarnost kao prediktor ideoloških obrazaca (Šram, 2016); autoritarnost i stav prema demokraciji (Čorkalo i Stanković, 2000, Čorkalo, Kamenov i Tadinac-Babić, 2001) i dr.

U okviru ove problematike nužno je navesti i opsežno istraživanje mladih Ilišin (2005). Ključni nalazi su da mladi znatnije prihvaćaju liberalne vrijednosti, da su mladi u gradu višeg obrazovanja skloniji modernističkim vrijednostima za razliku mladih na selu nižeg obrazovanja. Te se razlike odražavaju i na njihove političke preferencije.

\section{Istraživanja međunacionalnih odnosa}

U situaciji propasti jednog utopijskog političkog sustava, nacionalno pitanje, odnosno međunacionalni odnosi, ključna su varijabla raspada jedne višenacionalne zajednice. Istraživanje te problematike dobilo je drugačije značenje nego prije 1990., moglo se je istraživati bez ograničenja vlasti, i, svakako, s novim problemima s obzirom na traumatsko ratno razdoblje Domovinskog rata. 
$S$ jedne, relativno velike, vremenske distance moglo bi se pretpostaviti da je nacionalna vezanost i nacionalni identitet izrazito velik početkom 1990-ih, da bi se, s protokom vremena polako smanjivao, posebice imajući u vidu težnju $\mathrm{k}$ europskim integracijama. Isto je tako za pretpostaviti da će se negativan odnos prema onima s kojima smo bili u sukobu postupno smanjivati. Rezultati istraživanja nisu uvijek u skladu s tim pretpostavkama.

Radin (2005) iznosi podatak da u funkciji vremena raste nacionalna vezanost mladih. Analiza tri istraživanja, prvo provedeno 1986. (Flere, 1986), drugo u vrijeme još uvijek prisutne nacionalne euforije uspostavom samostalne države i pobjede u Domovinskom ratu 1999. godine (Baranović, 2002), i treće 2004. godine (Radin, 2005), znači u vrijeme demokratske stabilizacije i protoka vremena i u vrijeme ozbiljnih napora za ulazak u EU, pokazuje da je nacionalna vezanost sve veća.

Problem socijalne distance sustavno se istražuje u okviru projekta na Fakultetu političkih znanosti od 1992. godine. Priloženi grafikon ${ }^{21}$ (slika 1) pokazuje kako se socijalna distanca mijenja ovisno o društvenim okolnostima. Prva faza (Pantić, 1967), faza utopijskog optimizma, pokazuje izrazito malu socijalnu distancu $s$ obzirom na mogućnost braka, sukladnu maloj skupini krajnje isključivih ispitanika u okviru većeg broja istraživanja (Šiber, 1988). Druga faza (grupa autora, 1988) je na samom početku krize jugoslavenskog društva i socijalna distanca je na razini nađene distance u nizu istraživanja u svijetu. Treća faza je razdoblje ratnog sukoba i trauma i pokazuje izrazitu socijalnu distancu prema Srbima i Bošnjacima, a četvrta razdoblje 'oporavka' koja pokazuje da je distanca na razini uoči rata (slika 1$).{ }^{22}$

U istraživanju Šibera (1997) analizirana je socijalna distanca u odnosu na stranačku preferenciju. Sukladno očekivanju, spremnost na brak i koegzistenciju sa Srbima i Bošnjacima ovisi o položaju stranke na L - D dimenziji.

Istraživanja stereotipa, kao i u ranijem razdoblju, je relativno rijetko. Ovdje ćemo spomenuti rad Skoke (2008) koji uspoređuje stereotipe dobivene u istraživanjima Milosavljevića (2000) i Petrović (2005) s rezultatima svojih istraživanja provedenih 2007. i 2010. godine u BiH na uzorku sva tri konstitutivna naroda. Osnovni nalaz njegova rada je konstatacija da određeni 'povijesni' stereotipi dolaze do izražaja u godinama tzv. 'povijesnih' lomova, da bi se, s odmakom od ratnih sukoba, negativni stereotipi smanjivali. Kamenov i Čorkalo (1997) istraživale su, metodom SYMLOG, promjene stereotipa prema Hrvatima, Slovencima, Srbima i Albancima u tri navrata - 1991., 1993. i 1996. na uzorku studenata psihologije. Rezultati istraživanja pokazuju da je tijekom tih pet godina došlo do

21 Banka podataka Fakulteta političkih znanosti, Zagreb

22 Treća i četvrta faza prikazana je na temelju istraživanja (banka podataka) na Fakultetu političkih znanosti, Zagreb. 


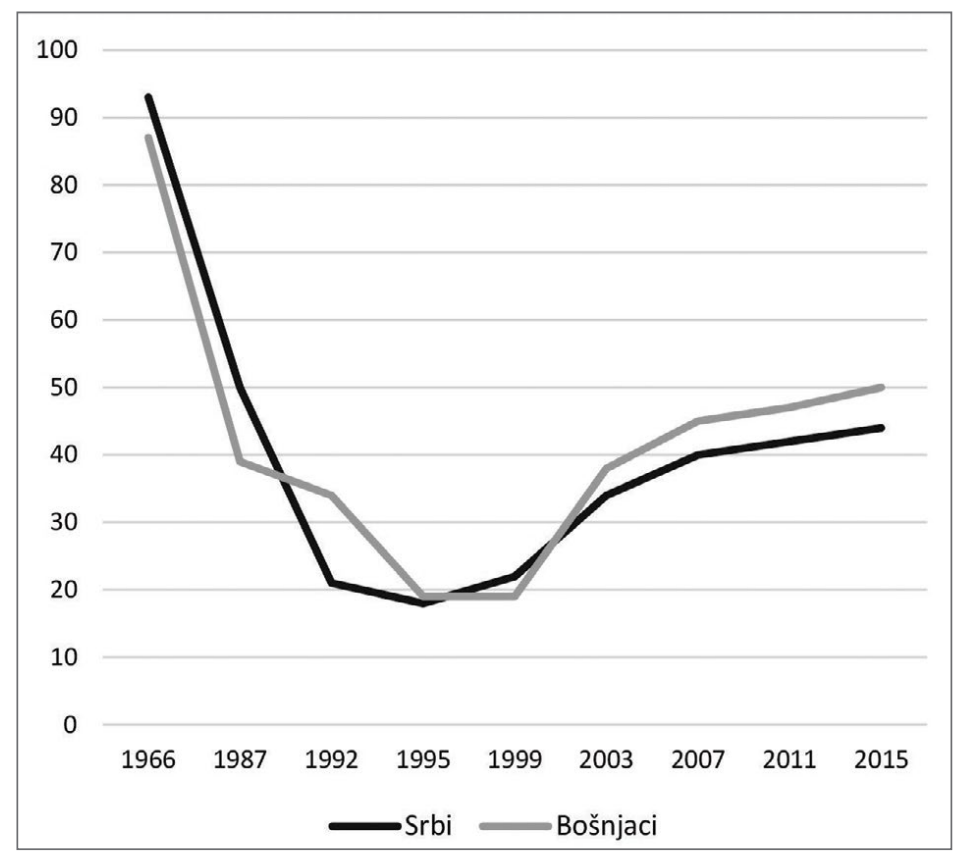

Slika 1. Socijalna distanca prema Srbima i Bošnjacima 1966 - 2015.

udaljavanja Hrvata i Slovenaca, odnosno do učvršćenja stereotipa prema Srbima i Albancima. Razlika u rezultatima ova dva istraživanja je, vjerojatno, uvjetovana vremenom u kome su provođena. Prvo istraživanje zahvaća vrijeme sukoba, dok drugo vrijeme stabilizacije.

Posebno interesantnu problematiku međunacionalnih odnosa sustavno istražuju Čorkalo Biruški i D. Ajduković (2009, 2012). U nizu istraživanja, većim dijelom longitudinalnog karaktera, primjenom različitih kvantitativnih i kvalitativnih metoda (uključivo etnografska istraživanja i metode fokus grupa), provedenim u Vukovaru počevši od 2000. godine, oni su, na primjeru jednog traumatiziranog i etnički podijeljenog grada, zahvatili tri dominantna problema: proces dekonstrukcije i rekonstrukcije traumatizirane zajednice (2009); analizu škole kao prostora socijalne integracije (2012), i problem političke socijalizacije mladih u post-konfliktnoj zajednici (2015). Ova istraživanja jedan su od rijetkih primjera (pored analize izbornih procesa na Fakultetu političkih znanosti) serioznih longitudinalnih istraživanja koja integriraju znanstvenu znatiželju i društvene potrebe, odnosno znanstveni doprinos razumijevanju aktualnih $i$ akutnih procesa i uočavanju nužnih koraka u željenim naporima društvene zajednice u prevladavanju postojećeg stanja.

\section{Istraživanje odnosa prema ulasku Hrvatske u Europsku Uniju}

U početku ovog prikaza smo naglasili da određene društvene situacije i problemi jednostavno traže znanstvene analize i time potiču razvoj same znanosti. Potencijal- 
ni ulazak u europske integracije prisutan je od konca 80 -ih godina prošlog stoljeća da bi nakon 2000. godine postao jedan od temeljnih ciljeva hrvatske politike. Početna istraživanja javnog mnijenja, prije svega agencije PULS, pokazivala su početnu snažnu podršku integraciji da bi s vremenom, što se mogućnost ulaska približavao, podrška opadala. Što je to zbog čega netko smatra da je za Hrvatsku korisno, a netko štetno ulazak u Uniju, ključno je pitanje koje postavljaju političke elite kao temelj svog djelovanja na opredjeljenje javnosti.

Interesantno je da su se istraživanja uglavnom usredotočila na odnos nacionalnog i europskih integracija. Tako Radin (2005) istražuje problem nacionalne vezanosti i odnos prema Europi, Kamenov, Jelić, Huić, Frančeško i Mihić (2006) odnos nacionalnog i europskog identiteta i stavova prema EU integracijama, dok Lamza-Posavec (2006) istražuje problematiku nacionalnog ponosa i otvorenosti za EU integracije.

Grupa istraživača s Fakulteta političkih znanosti problematici odnosa prema EU pristupila je $s$ različitih aspekata ${ }^{23}$ pokušavajući dati što cjelovitiji i kompleksniji uvid kako u razloge svojevrsnog EU skepticizma, tako i razloge zbog kojih se neki odlučuju podržati taj ključni politički projekt. Od niza priloga ovdje ćemo se zadržati samo na onim istraživanjima koja neposredno spadaju u problematiku političke psihologije i koja, na različitim uzorcima i različitim metodama istražuju isti problem - čemu se nadamo i čega se plašimo ulaskom u Europsku Uniju. ${ }^{24}$

Blanuša (2011) istražuje problem euroskepticizma na temelju rezultata istraživanja javnog mnijenja agencije Ipsos Plus. Primjenom faktorske analize pojedinačnih očekivanja od priključenja EU dobiva četiri temeljna faktora: ugroženost samostalne egzistencije nacije, kulturno-politička ugroženost nacije, uspostava pravne države, i poboljšanje međunarodnog ekonomskog i političkog položaja. Zanimljiv je podatak da s približavanjem EU kroz godine dolazi do stapanja prva dva i druga dva faktora u smislu negativnih euroskeptičnih i pozitivnih euroentuzijastičkih očekivanja.

U radu Blanuše i Šibera (2011) istoj problematici pristupilo se metodološki na drugačiji način. U okviru redovite nastave Hrvatskog jezika u srednjim školama učenici 3. razreda su pisali rad na temu čega se plaše i čemu se nadaju od ulaska Hrvatske u Europsku Uniju. Za razliku od klasičnih upitnika gdje je ispitanik suočen s ponuđenim odgovorima, ovdje ispitanik spontano piše o temi navodeći svoje stavove. Nakon ocjenjivanja zadaća predmetnog nastavnika, primijenjena je metoda analize sadržaja kako bi se dobio uvid u način razmišljanja i preokupacije mladih. Metoda usmjerenih asocijacija putem samostalnih pripovjednih odgovora omogućava puno veću spontanost u artikulaciji mišljenja nego anketa. Posebno je analizirana faktorska struktura strahova a posebno faktorska struktura nada.

23 Radi se o istraživačkom projektu Javnost, elite, mediji i komunikacijska strategija ulaska Hrvatske u Europsku Uniju koji je financiralo Ministarstvo znanosti, obrazovanja i športa 2007- 2014.

24 Upravo je to i sadržano u naslovu knjige koja sadrži radove u okviru projekta: Hrvatska i Europa strahovi i nade! 
Kod strahova dobivena su četiri faktora 2. reda: strah od političkih promjena (gubitak suvereniteta, opći strah od neizvjesnosti); strah od strogih nasuprot proizvoljnih kriterija (uništenja domaće proizvodnje, kriminalizacija Domovinskog rata); strah od ekonomske kolonizacije (pad standarda, eksploatacija resursa i rasprodaja); strah od gubitka kulture i identiteta.

Kod nada dobivena su također četiri faktora 2. reda: vanjsko politički napredak; ekonomski napredak; odgovorno upravljanje; Hrvatska kao Europa.

Skoko i Bagić (2011) isti problem istražuju metodom fokus grupe. Tu se radi o kvalitativnom obliku istraživanja koji uključuje grupnu diskusiju na zadanu temu. Osnovni cilj je potaknuti dubinsku diskusiju kojom će se istražiti stavovi ili vrijednosti sudionika o nekom problemu ili temi, odnosno razumjeti i objasniti značenja, vjerovanja i kulturu koja utječe na osjećaje, stavove i ponašanja pojedinca. $U$ ovom pristupu autori su se usredotočili na razloge protiv ulaska Hrvatske u Europsku Uniju. U zaključku, navedeno je 29 razloga protiv ulaska koji su grupirani u pet temeljnih uvjerenja:

- EU je zajednica neravnopravnih, čijom politikom dominiraju interesi najvećih članica, a ne zajednički;

- EU i njegove najznačajnije članice imaju nepošten odnos prema Hrvatskoj;

- Slobodna trgovina i konkurencija štete Hrvatskoj;

- Hrvatska je slaba ekonomski i politički;

- U pogledu prirodnih potencijala Hrvatska je 'raj na zemlji'.

\section{Umjesto zaključka}

Veoma je teško u okviru sažetog pregleda jednog područja psihologijskog istraživanja obuhvatiti svu raznolikost istraživačkog interesa. Samo kao primjer, navest ćemo jedan broj problema koji su zaokupljali istraživače a ovdje ih nismo posebno razmatrali. To su problemi konformizma (Šiber, 1984), povijesne svijesti mladih (Blanuša, 2002, 2005), političke tolerancije (Vujević, 1996), vrednovanja povijesnih ličnosti Hrvatske (Sekulići Šporer, 2007), vrijednosti hrvatskog društva (Rimac, 2016), itd.

Ovaj sažeti prikaz razvoja političke psihologije u Hrvatskoj pokazuje da je u proteklih skoro 60 godina došlo do naglog širenja psiholoških istraživanja daleko izvan tradicionalnih usko psiholoških problema. Znatiželja istraživača, ali i sve veće društvene potrebe za razumijevanjem složenih društvenih zbivanja, dovele su do toga da su psihološke spoznaje postale nezaobilazan dio svake ozbiljne političke analize, ali i pretpostavka racionalne društvene prakse. Isto tako, kako se društvo otvorilo prema spoznajama psihologije, tako se i psihologija otvorila prema društvu, ali, nužno, i prema potrebi interdisciplinarnih istraživanja. Tradicionalne psihološke metode postaju temelj bihevioralnih analiza i u drugim znanstvenim 
oblastima, a teorijski koncepti drugih znanosti polazišta i okvir interpretacija psiholoških analiza. Posebno snažan utjecaj razvoj političke psihologije je imao i ima, na razvoj suvremene politologije, prije svega na njen bihevioralni pristup, koji se, uz normativni i teorijski, uzima kao treći temeljac suvremene politologije.

Brojna istraživanja u proteklom razdoblju, kao i veći broj kako formalno školovanih (kroz doktorske studije) tako i oformljenih istraživača kroz osobne napore, stvorili su nužnu kritičnu masu (spoznajnu i kadrovsku) koja omogućava, ukoliko za to postoji interes i potreba, određene specijalističke studije u suradnji, prije svega, s politolozima i sociolozima.

\section{Literatura}

Adorno, T.W., Frenkel-Brunswik, E., Levinson, D.J., \& Sanford, R.N. (1950). The Authoritarian Personality. New York: Harper.

Almond, G., \& Verba, S. (1963). The Civic Culture: Political Attitudes and Democracy in Five Nations. New Jersey: Princeton University Press.

Bahtijarević, Š., Zvonarević, M. i Šiber, I. (1989). Javno mnijenje Zagreba '88. Naše teme, $337-8$.

Baranović, B. (2002). Mladi u Hrvatskoj: između nacionalnog identiteta i europske integracije. U: Ilišin, V. i Radin, F. (ur.), Mladi uoči tréég milenija (str. 125-154). Zagreb: IDIS, Državni zavod za zaštitu obitelji, materinstva i mladeži.

Benc, M. (1970). Politička kultura građana i anketna istraživanja u Hrvatskoj, Politička misao, 1.

Benc, M. (1974). Izborno ponašanje gradana. Zagreb: IDIS.

Blanuša, N. (2002). Socijalno politička očekivanja mladih u Hrvatskoj u modelu povijesne svijesti. Politička misao, 39(1), 88-108.

Blanuša, N. (2004). Povijesna svijest mladih u Hrvatskoj i Europi: pitanja strukture, koherencije, rascjepa i vremenske stabilnosti. Neobjavljen magistarski rad. Zagreb: Fakultet političkih znanosti u Zagrebu.

Blanuša, N. (2005). Povijesna svijest mladih u Europi na prijelazu milenija, Politička misao, 42(3), 65-88.

Blanuša, N. (2011). Teorije zavjera i hrvatska politička zbilja 1980-2007. Zagreb: Plejada.

Blanuša, N. (2011). Euroskepticizam u Hrvatskoj. U: Šiber, I. (ur.), Hrvatska i Europa strahovi i nade (str. 11-46). Zagreb: Fakultet političkih znanosti Sveučilišta u Zagrebu.

Blanuša, N. i Šiber, I. (2011). Nade i strahovi mladih prema Europskoj Uniji. U: Šiber, I. (ur.), Hrvatska $i$ Europa -strahovi i nade (str. 86-119). Zagreb: Fakultet političkih znanosti Sveučilišta u Zagrebu.

Blanuša, N. (2013). Internal memory divided: Conspiratorial thinking, ideological and historical cleavages in Croatia - lessons for Europe. European Quarterly of Political Attitudes and Mentalities, 2(4), 16-33.

Blanuša, N. (2015). Drugi svjetski rat kao transgeneracijska trauma: sablasti prošlosti među mladima u Hrvatskoj. U: Ilišin, V., Gvozdanović, A. i Potočnik, D. (ur.), Demokratski potencijali mladih u Hrvatskoj (str. 125-144). Zagreb: IDIS i Centar za demokraciju i pravo Miko Tripalo. 
Blanuša, N. (2017). Trauma and Taboo: Forbidden political Questions in Croatia. Croatian Political Science Review, 54(1-2), 170-196.

Bogardus, E.S. (1925). Measuring Social Distances. Journal of Applied Sociology, 9(4), 299-308.

Bovan, K. (2016). Rekonstrukcija i eksperimentalna provjera koncepta točnog glasovanja. Neobjavljen doktorski rad. Zagreb: Fakultet političkih znanosti u Zagrebu.

Bovan, K., Banai, I.P., \& Banai, B. (2016). Vocal characteristics of presidential candidates can predict the outcome of actual elections. Evolution \& Human Behavior, 38(3), 309-314.

Campbell, A. (1962). The Passive Citizen. Acta Sociologica - Scandinavian Review of Sociology, 6(1-2).

Čorkalo, D. i Stanković, N. (2000). Autoritarnost i percepcija ostvarene demokracije u Hrvatskoj: analiza odnosa na uzorku studenata, Društvena istraživanja, 9(1).

Čorkalo, D., Kamenov, Ž. i Tadinac-Babić, T. (2001). Autoritarnost, stav prema stanju demokracije i percepcija razvojnih ciljeva Hrvatske. Društvena istraživanja, 10(6), 1159-1177.

Čorkalo Biruški, D. i Ajduković, D. (2009). Od dekonstrukcije do rekonstrukcije traumatizirane zajednice: primjer Vukovara. Revija za socijalnu politiku, 16(1), 1-24.

Čorkalo Biruški, D. i Ajduković, D. (2012). Škola kao prostor socijalne integracije djece i mladih u Vukovaru. Zagreb: Zaklada Friedrich Ebert.

Čorkalo Biruški, D., Reidy, C.M., Taylor, L.K., Merrilees, C.E., Ajduković, D., \& Cummings, E.M. (2015). The Political Socialization of Youth in a post-conflict community. Interanational Journal of Intercultural Relations, 45, 11-23.

Dahrendorf, R. (1992). Betrachtungen die Revolution in Europa in einem Brief, der an einen Hern in Warchau gerichtet ist. Stuttgard, FRG: Deutsche Verlags-Anstalt GMBH.

Dalton, R.J. (1986). Political Cleavages, Issues, And Electoral Change. In: LeDuc, L., Niemi, R.G., and Norris, P (Eds.), Comparing Democracies - New Challenges in the Study of Elections and Voting. London: Sage.

Džinić, F. (1965). Jugoslavensko javno mnijenje i VIII Kongres SKJ. Beograd: IDN.

Đurić, Đ. (1980). Psihološka struktura etničkih stavova kod mladih. Novi Sad.

Eulau, H. (1963). The Behavioral Persuasion in Politics. New York: Random House.

Eysenck, H. (1944). General Social Attitudes. Journal of Social Psychology, 19, 207-227.

Eysenck, H. (1954). The psychology of politics. London: Routledge-Kegan Paul.

Ferguson, L. (1939). Primary Social Attitudes, Journal of Psychology, 8, 217-223.

Flere, S. (1986). Odnos mladih prema etnosu. U: Aleksić i dr. (ur.), Položaj, svest i ponašanje mlade generacije Jugoslavije. Beograd-Zagreb: CIDID-IDIS.

Grdešić, I. i Šiber, I. (1991). Izbori i Politička znanost. U: Grdešić i dr.: Hrvatska u izborima1990. Zagreb: Naprijed.

Grupa autora, Beograd (1986). Beograd: Materijali IDN.

Grupa autora, FPZ (1982). Zagreb: Materijali FPZ.

Grupa autora, (1988). Ljubljana: Materijali Instituta pri FDV.

Guetzkow, H. (1955). Multiple loyalities. Princeton: Princeton Unversity Press.

Hermann, M.G. (Ed.) (1986). Political Psychology - Contemporary Problems and Issues. San Franciso: Jossey-Bass publ.

Ilišin, V. (2005). Političke vrijednosti, stavovi i participacija mladih - kontinuitet i promjene. U: Ilišin, V. (ur.), Mladi i europska integracija (str. 65-139). Zagreb: IDIS.

Janda, K., Berry, J.M., \& Goldman, J. (1989). The Challemge of Democracy. Boston: Houghton Mifflin Co. 
Jerbić, V. i Lukić, S. (1979). Idejna kretanja i konfliktna žarišta u redovima mladih u SR Hrvatskoj. Zagreb: Savjet za prosvjetno pedagošku službu SRH.

Kamenov, Ž. i Čorkalo, D. (1997). Mjerenje promjena nacionalnih stereotipa: primjena metode SYMLOGa. Društvena istraživanja, 6(2-3), 361-372.

Kamenov, Ž., Jelić, M., Huić, A., Frančeško, M. i Mihić, V. (2006). Odnos nacionalnog i europskog identiteta i stavova prema europskim integracijama građana Zagreba i Novog Sada. Društvena istraživanja, 15(4-5), 867-890.

Kasapović, M. (1987). Delegatski izbor 1976 - 1986. Zagreb: FPZ.

Knutson, J.N. (1973). Handbook of Political Psychology. New York: Jossey-Bass Publisher.

Lamza Posavec, V. (2004). Apstinencija na izborima za Hrvatski sabor 2003. godine: tko i zašto nije glasovao. Društvena istraživanja, 13(3), 383-404.

Lamza Posavec, V., Ferić, I. i Rihtar, S. (2006). Nacionalni ponos i otvorenost za europske integracije. Društvena istraživanja, 15(1-2), 141-153.

Lazaroski, J. (1975). Povezanost oblika nacionalne vezanosti sa socijalnom distancom, V. Kongres psihologa Jugoslavije. Skopje.

Lewin, K. (1951). Field Theory in Social Science. New York: Harper.

Lippman, W.(1922). Public opinion. New York: The Macmillan.

Magdalenić, I. (1969). Mišljenje o društveno-političkim problemima. U: Caratan, B., Magdalenić, I. i Šiber, I. (ur.), Idejno-Političke tendencije među omladinom i studentima (šapirografirano). Zagreb: Naše teme.

Marx, K. i Engels, F. (1953). Rani radovi. Zagreb: Kultura.

Meloen, J.D., Farner, R., \& German, D.B. (1994). Authoritarianism and Democracy - Evidence from Twelve Countries World Wide. U: Csepeli, G., et al (Eds.), From Subject to Citizen. Budapest: Hungarian Studies, Hungarien Center for Political Education.

Milas, G. (1998). Multivarijantna i eksperimentalna studija odnosa temeljnih dimenzija društvenih stavova, ličnosti i društvene poželjnosti. Neobjavljen doktorski rad. Zagreb: Filozofski fakultet u Zagrebu.

Milas, G. i Rimac, I. (1994). Model hrvatskog političkog prostora, dimenzioniran stavovima Glasača. Revija za sociologiju, 25(1-2), 9-22.

Miller, G.A. (1976). The Psychology of Communication. New York: Penguin Books, The MacMillan, Co.

Milosavljević, O. (2000). Stereotipi o drugima kao opravdanje (argumentnacionalizma. Primer: srpski ntelektualci o Hrvatima). U: Fleck, H.G. i Graovac, I. (ur.), Dijalog povjesničaraistoričara, 1. Zagreb: Zaklada Friedrich Naumann.

Novosel, P. (1969). Politička kultura u Hrvatskoj. Zagreb: SSRNH.

Pantić, D. (1967). Etnička distanca u SFRJ. Beograd: IDN.

Pantić, D. (1977). Vrednosti i ideološke orijentacije društvenih slojeva. Beograd: IDN.

Park, R.E. (1924). The Concept of Social Distance As Applied to the Study of Racial Attitudes and Racial Relations. Journal of Applied Sociology 8, 339-344.

Peršič, B. (1973). Još jedna verzija skale za ispitivanje oblika nacionalne vezanosti. Dani Ramira Bujasa. Zagreb: DPH.

Petrović, N. (2005). Psihološke osnove pomirenja izmedu Srba, Hrvata i Bošnjaka. Beograd: Institut za psihologiju, Filozofski fakultet.

Prpić, I. (2002). Spomenica Fakulteta Političkih znanosti u Zagrebu - 1962-2002. Zagreb: FPZ.

Radin, F. (2005). Nacionalna vezanost i EU integracija. U: Ilišin, V. (ur.), Mladi Hrvatske i europska integracija (str. 173-194). Zagreb: IDIS. 
Radin, F., Kregar, J., Magdalenić, I., Petković, S. i Rimac, I. (1990). Neke mjerne karakteristike autoritarnosti. Primijenjena psihologija, 11(2), 99-106.

Riesman, D. (1965). Usamljena gomila. Beograd: Nolit.

Rimac, I. (1999). Osnovne psihološke odrednice formiranja političkih preferencija. Neobjavljen doktorski rad. Zagreb: Odsjek za psihologiju Filozofskog fakultet u Zagrebu.

Rimac, I. (2016). Vrijednosti u hrvatskom društvu i mogućnost političkog konsenzusa. U: Sekulić, D. (ur.), Vrijednosti u hrvatskom društvu (str. 109-135). Zagreb Centar za demokraciju i pravo Miko Tripalo.

Rot, N. (1975). Pokušaj istraživanja tipova nacionalne vezanosti. V. Kongres psihologa Jugoslavije, Skopje.

Rot, N. i Havelka, N. (1972). Izrada skale za ispitivanje oblika nacionalne vezanosti. Ljubljana: 4. Kongres psihologa Jugoslavije.

Rot, N. i Havelka, N. (1973). Nacionalna vezanost i vrednosti srednjoškolske omladine. Beograd: IDN.

Sekulić, D. i Šporer, Ž. (2007). Vrijednosne i socijalne odrednice u ocjenjivanju povijesnih ličnosti. Revija za sociologiju, 38(1-2), 3-23.

Skoko, B. (2008). Imidž Hrvatske u zemljama nastalim na području bivše Jugoslavije.

Neobjavljen doktorski rad. Fakultet političkih znanosti Sveučilišta u Zagrebu. (Objavljen kao knjiga: Hrvatska i susjedi: Kako Hrvatsku doživljavaju u Bosni i Hercegovini, Crnoj Kori, Makedoniji i Srbiji, 2010, Zagreb: AGM.)

Skoko, B. (2010). Moć stereotipa: Srbi o Hrvatima - prije, za vrijeme i nakon sukoba. U: Cipek, T. (ur.), Kultura sjećanja 1991. Povijesni lomovi i svladavanje prošlosti (str. 93-108). Zagreb: Disput.

Skoko, B. i Bagić, D. (2011). Pet uvjerenja i 29 razloga protiv. U: Šiber, I. (ur.), Hrvatska i Europa-strahovi nade (str. 47-85). Zagreb: Fakultet političkih znanosti Sveučilišta u Zagrebu.

Stanford, N. (1973). Authoritarian personality in contemporary perspective. U: Knutson, J.N. (Ed.), Handbook of Political Psychology. New York: Jossey-Bass Publisher.

Supek, R. (1963). Psihosociologija radne akcije. Beograd: Mladost.

Šiber, I. (1970). Psihologijska analiza izbornog ponašanja. Neobjavljen magistarski rad. Zagreb: Odsjek za psihologiju Filozofskog fakulteta u Zagrebu.

Šiber, I. (1974). Socijalna struktura i politički stavovi. Zagreb: CAPS.

Šiber, I. (1984). Psihologija i društvo. Zagreb: Centar za kulturnu djelatnost.

Šiber, I. (1988). Psihologijski aspekti međunacionalnih odnosa. Zagreb: Kulturni radnik.

Šiber, I. (1989). Autoritarna struktura ličnosti - kritički prikaz jugoslavenskih istraživanja. Politička misao, 26(1), 129-145.

Šiber, I. (1993). Structuring the Croatian Party Scene. Politička misao, 30(2), 111-131.

Šiber, I. (1997). War and the Changes in Social Distance Toward the Ethnics Minorities in Croatia. Politička misao, 34(5), 3.26.

Šiber, I. (1998). Osnove političke psihologije. Zagreb: Politička kultura.

Šiber, I. (2007). Političko ponašanje - istraživanja hrvatskog društva. Zagreb: Politička kultura.

Šiber, I. (2007). Političko ponašanje birača u izborima 1990-2003. U: Šiber, I. Političko ponašanje - istraživanja hrvatskog društva. Zagreb: Politička kultura.

Šiber, I. i Tomac, Z. (ur.) (1986). Delegatski sistem 1974 -1984. Zagreb: Informator.

Šram, Z. (2007). Društveni karakter, politička kultura i struktura ličnosti: komparativna analiza zagrebačkih i beogradskih studenata. Neobjavljen doktorski rad. Zagreb: Fakultet političkih znanosti u Zagrebu. 
Šram, Z. (2016). Materijalistička i prosocijalna orijentacija, desna autoritarnost i orijentacija socijalnoj dominaciji kao prediktori ideoloških obrazaca kod građana istočne Slavonije i Baranje U: Babić, D. i dr. (ur.), Slavonija - hrvatska i europska regija (str. 83-128). Zagreb: Institut za migracije i narodnosti.

Thurstone, L. I. (1928). Attitudes can be measured. American Journal of Sociology, 33(4), 529-554.

Thurstone, L. I. (1931). The measurement of political attitudes. The Journal of Abnormal Social Psychology, 26, 249-269.

Todd, E. (1988). Making of Modern France: Ideology, Politicies and Culture. New Jersey: Black Well Publisher.

Toš, N. (1999). Podobe o cerkvi in religiji. Ljubljana: FDV IDV Dokumenti, SJM.

Vroom, V. H. (1964). Work and Motivation, New York: Wiley.

Vujević, M. (1996). Politička tolerancija u Hrvatskoj. Politička misao, 33(1), 129-148.

Wallas, G. (1909). Human Nature in Politics. Boston: Houghton Mifflin.

Zvonarević, M. (1976). Socijalna psihologija. Zagreb: Školska knjiga.

Zvonarević, M. i dr.(1969). Istraživanje javnog mnijenja u SRH. Zagreb: IDIS.

Zvonarević, M. i dr. (1971). Istraživanje javnog mnijenja u SRH. Zagreb: IDIS.

Zvonarević, M., Kljaić, S. i Šiber, I. (1966). Neki aspekti izbora za općinske skupštine u Zagrebu 1965. godine. Politička misao, 3(1-2), 75-88. 